evidence which would show that they had actually seen the book to which they refer. We have gathered information about all Wingate's mathematical books which De Morgan did not examine. We shall state where copies can be found, so that the data given here can be verified by those who are near the libraries named. We take up Wingate's books, one after the other, and show that none contains the slide rule.

(1) "L'Usage de la Règle de Proportion," Paris, I624. De Morgan's assertion that this book describes nothing more than Gunter's scale ${ }^{1}$ is corroborated by P. M. N. Benoit, ${ }^{2}$ who examined copies in the Bibliotheque nationale and the Bibliotheque Mazarine in Paris. There is a copy in the Bodleian Library.

Wingate brought out in 1626 in London a translation under the title "Use of the Rule of Proportion." Later editions appeared in $1628,1645,1658$, and 1683 . De Morgan saw the 1645 edition, a copy of which is in the British Museum. Wingate died in 1656 .

(2) "Arithmétique logarithmique," Paris, 1626. De Morgan described this book. " He saw also the "Logarithmeticall Table," London, 1635, which is anonymous, but is attributed to Wingate.

(3) "Construction and Use of the Line of Proportion," London, 1628. Copy in the British Museum. The "line of proportion" here described is merely a mechanical table of logarithms. There are no sliding parts.

(4) "Of Naturall and Artificiall Arithmetique," London, 1630. Copy in the Bodleian Library. Describes only the instrument named in the preceding text. The first part of this book was enlarged by John Kersey the elder in 1650 under the new title "Arithmetique Made Easie." De Morgan saw the editions of 1673 and $17600^{5}$ The second part was re-edited by Wingate in 1652 . Copy in the British Museum. The instrument described here is still the "line of proportion."

(5) "Ludus Mathematicus," London, 1654, 1681. De Morgan ${ }^{B}$ inspected the first edition.

(6) "Use of the Gauge-rod," London, $165^{8}$ (second edition).

(7) "The Clarks Tutor for Arithmetick and Writing ... being the Remains of Edmund Wingate," London, i671. Copies of both books in the Bodleian Library. Neither contains an account of the slide rule.

\section{MASONRY ARCHES}

A MEMOIR dealing with a subject of great interest to the engineer has recently been issued as a Drapers' Company Research Memoir. ${ }^{1}$ It must be admitted that the ordinary treatment of the masonry arch is by no means satisfactory, and therefore any solution of the problem which would give more accurate and trustworthy results without involving excessive labour in the necessary calculations would be welcomed by every engineer who may in the course of his professional duties have to deal with the design and erection of masonry or brick arches.

After discussing the ideal arches for different load conditions, the authors show that for the fairly flat arches of modern practice designed to carry (I) a uniform load per foot run of the rib, or (2) a vertical load rising to a horizontal at a height $l^{2} / 8 r+r / 6$ above the central line at the crown, the elliptic arch is the proper design.

The rest of the memoir is devoted to an investigation of the extent of the applicability of the elliptic arch. It is shown that for the loads usual in masonry arches the elliptic arch is only closely approximate to the ideal if the ratio of rise to span be small, this latter condition involving large horizontal thrusts and great compressive stresses.

The authors then show that a close approximation to the arch the line of pressure of which coincides with its central line can be obtained with no great labour of calculation, and such an arch they term a pseudo-elliptic arch.

1 "Arithm. Bnoks," p. 42.

2 "La Règle à Calcul expliquee," p. vi. (Paris, 1853.)

3 " Penny Cyclop.,", Art. "Tables," p. 497. 4 "Loc. cit., p. 498.

5 "Arithm. Books," pp. 48, 73

6. Op. cit., p. 44

7 "On a Practical Theory of Elliptic and Pseudo-elliptic Arches, with Special Reference to the Ideal Masonry Arch." By Prof. Karl Pearson W. D. Reynolds, and W. F. Stanton. Pp. $23+6$ plates. Drapers' Company Research Memoirs, Technical Series, VI. (London: Dulau and Co., rgog.)
Price 4 s.

NO. 2096, VOL. 82]
The necessary equations to give the required solution are obtained, and an example is worked out in detail to show the application of the method and to prove that the labour of the necessary calculation is not a serious obstacle to the employment of this method. The memoir is illustrated by six plates reproduced from actual drawings.

The applied mathematics department of University College is to be congratulated on this valuable addition to the series of research memoirs dealing with difficult engineering problems for which Prof. Karl Pearson and his students have been responsible. $\quad$ T. H. B.

\section{UNIVERSITY AND EDUCATIONAL INTELLIGENCE:}

Graduates of the late Royal University of Ireland who desire to be registered as graduates of the Queen's University of Belfast, or enrolled as 'members of Convocation, should communicate as early as possible with the secretary of the latter University. The first meeting of Convocation must be held within the next four months.

WE learn from Science that, according to figures available in the office of the auditor, the University of Chicago holds investments representing permanent endowment that amount to $2,974,000 l$. In addition, its buildings and grounds devoted entirely to university use represent $1,783,540 l .{ }^{\circ}$; equipment, scientific apparatus, furniture, \&c., being put at $383,260 l$. additional. These figures do not include the funds destined for the erection of the Harper Memorial Library, estimated in round figures to cost $180,000 l$., nor the cost of the classical building, the construction of which is in contemplation, and on which about $50,000 l$. will be expended.

Dr. Charles Graham, at one time professor of chemistry at University College, London, and a prominent member of the Society of Chemical Industry, who died on November I3, has left the residue of his estate for medical research. The amount available will probably be $35,000 l$., and it is left to the Senate of the University of London to found a fund, to be known as the Charles Graham Medical Research Fund. The fund is to be applied in aid of any research carried on by a teacher or student of the school of advanced medical studies of the University College Hospital for the prevention, cure, or alleviation of human disease or suffering. If any student or teacher conducts a research which is considered of sufficient merit a gold medal of appropriate value is to be awarded to him. The committee of the school is also to pay to such teacher or student conducting the research an annual sum not exceeding $200 l$. per annum for two years, such person to be known as the "Charles Graham Student in Pathology."

THE Department of Agriculture and Technical Instruction for Ireland has issued a syllabus (Circular 70) of the examination which it proposes to hold in the princtples, methods, and history of education, with special reference to science teaching. The examination will be held in June of each year. The examination is provided for candidates seeking recognition of qualification to teach science. Among the subjects included in the syllabus are:-The general characteristics of the curriculum and methods of instruction in science as determined by the laws of general development; the correlation of science with other subjects of the curriculum. The methodology of instruction in science as determined by the laws of development of knowledge; the functions and relations of laboratory work and class-teaching. The critical study of the history of a special branch of science so far as it bears upon the teaching of the subject. The use of note-books and textbooks in science teaching; methods of recording and treating observational data. The construction and use of pictorial illustrations, diagrams, and models; the construction of apparatus. Laboratory organisation and management.

THE "Regulations for Secondary Schools" of the Board of Education lays it down that in all fee-charging secondary schools free places must be offered, under certain conditions, at the beginning of each school year to pupils entering from public elementary schools. The number of such places offered must ordinarily be 25 per cent. of the total number of pupils admitted to the school during the previous 
year, or, in the case of a new school, at its opening, but this percentage may be reduced or varied by the Board on sufficient grounds in the case of any particular school. A return has just been issued showing the number and names of the fee-charging secondary schools receiving the Board's full grant in which the 25 per cent. of free places has been reduced or varied on grounds deemed sufficient by the Board of Education. The return shows there are 865 secondary schools receiving from the Board the full scale of grant of $5 l$. for each registered pupil between twelve and eighteen years of age. At two of these schools no fees are charged, 746 are required to offer 25 per cent. of free places, and in the remaining II 7 a lower percentage is required. The grounds for variation or reduction of the normal percentage of free places fall roughly under three heads, viz. financial circumstances, the fact that there is an adequate provision of free places in neighbouring schools, and the existence of a large percentage of boarders in the school. In fifty-three cases the number of free places has been reduced from 25 per cent. to Io per cent., in twentynine cases to 12.5 per cent., in thirteen cases to 15 per cent., and in all other cases where a reduction has been allowed to 20 per cent.

THE eighth annual report, which deals with the work of the year 1908-9, of the executive committee of the Carnegie Trust for the Universities of Scotland has now been issued. The committee states that reports of the independent authorities who have examined the records of the year's work under the research scheme of the trust give evidence that its past success is being well maintained. The committee acknowledges the assistance rendered by the universities in providing the scheme with so many able workers and in affording accommodation and supervision in their various laboratories. We notice that applications for fellowships, scholarships, and grants for 1910-i I must be lodged on or before April I next with the secretary of the trust, from whom application forms and regulations can be obtained. The expenditure for 1908-9 upon the scheme of fellowships, scholarships, and grants, and upon the laboratory, was respectively $686 \mathrm{I} l$. and I992l., towards the latter of which the Royal College of Physicians and the Royal College of Surgeons together contributed roz 5 l. The second quinquennial scheme of distribution, which opened with the year under review, besides making contributions of $65,250 l$. to buildings and permanent equipment, and $20,500 l$. to libraries, will at the close of the period of five years have increased the resources of teaching in the four university centres by permanent endowments amounting to $87,500 l$, while it will at the same time have afforded during the five years an annual income of some 4I5ol. to meet ordinary expenditure. Statistics of the payment of class fees for 1908-9 give the total number of beneficiaries as 3553 , the total amount of fees paid as $47,07 \mathrm{rl}$., and the average amount of fees paid per beneficiary as $13 l$. 4s. IId., an increase as compared with the preceding academic year of 284 beneficiaries, of $3815 l$. in the total expenditure, and of threepence in the average amount per beneficiary. During the year 257l. 10s. $6 d$. was refunded voluntarily on behalf of eleven beneficiaries for whom class fees had been paid by the trust.

THE recommendations, made jointly by several of its subcommittees, to the London Education Committee for the organisation of a system of central schools in London have been adopted by the Education Committee, with the exception of a few relating to certain points concerning the teaching staff, and the consideration of these has been deferred. A system of schools is to be established giving an educational course not provided in existing elementary or secondary schools, and the new schools, which will be known as central schools, will have either an industria or a commercial bias, or both. These schools will take the place of the existing higher elementary and higher grade schools, and will be fed by contributions from surrounding schools, as most of the higher grade schools are at present. The curriculum will provide in all cases for manual and practical work, and, in the case of girls, for instruction in domestic subjects. The curriculum of each school will be considered specially, and be determined with the view of meeting the needs of the district. Pupils will be selected between the ages of eleven and twelve, and parents will be given the opportunity of choosing either a secondary school or a central school for these children. The schools will be organised on a four years' course, and provision will be made for bursaries to be held by pupils on their attaining the age of fourteen. These bursaries will not exceed 500 in number, and will consist of maintenance grants from the age of fourteen at the rate of Iol. a year. The total annual cost of this arrangement is estimated at 7500 . It is intended that the number of central schools shall be fewer than the present higher elementary and higher grade schools, and shall be carried on under the ordinary regulations of the Board of Education, and in this way be free from the restrictions imposed by the higher elementary schools' regulations. In order that the parents of candidates for admission may be given an opportunity of realising the advantages afforded by the new schools, it is intended to issue a short descriptive pamphlet, and the parents are to be encouraged to seek personal interviews with the school managers and head teachers.

THE eighth annual meeting of the North of England Education Conference will be held at Leeds; in the University buildings, on January $6-8$, under the presidency of Sir Nathan Bodington, Vice-Chancellor of the University. The general conference on Friday morning will be devoted to a discussion on the relation of elementary schools to technical schools (day and evening), which will be introduced by papers by Prof. M. E. Sadler, of Manchester, and Mr. James Baker. Mr. J. H. Reynolds and Mr. A. C. Coffin will open the discussion. The subject for the general conference on Saturday morning will be education abroad and in England-a comparison, introduced by papers by Mr. J. C. Medd and Mr. Otto Siepmann, head of the modern languages department, Clifton College. $\mathrm{Mr}$. Cloudesley Brereton and Dr. R. M. Walmsley will open the discussion. The sectional meetings on Friday afternoon will be devoted to the following four topics:(I) independent study and self-help in schools; (2) cooperation between employers and education authorities; (3) colour-study in relation to general art and to trade, and modern developments of applied art instruction; and (4) the teaching of geography and history in relation to one another. The sectional meetings on Saturday afternoon will be devoted to the four subjects :-(I) physical training in schools, with special reference to the new scheme of the Board of Education; (2) do we teach too many subjects in the primary schools? (3) modern ideas on general art instruction; and (4) the relation of the State to the training of teachers of domestic science, and their relation to the university. The last subject will be introduced by Prof. Smithells, F.R.S., and Miss M. Atkinson. It will be seen that the organising committee has selected a series of topics of wide interest and importance. The principal speakers are experts in their subjects. As a good attendance is already guaranteed, the conference should be one of particular interest and utility. The social side of the conference will be promoted by a conversazione at the University on Thursday evening, January 6 , and by $a$ reception by the Lord Mayor in the City Art Gallery on Friday evening, January 7. The usual publishers' exhibition will be liberally accommodated in the large physics laboratory at the University, and the comfort of delegates has been carefully considered in the provision of writing, smoking, and conversation rooms. The technological departments of the University will be open to delegates throughout the conference.

\section{SOCIETIES AND ACADEMIES. LONDON.}

Zoological Society, December 14.-Mr. G. A. Boulenger, F.R.S., vice-president, in the chair.-Dr. F. D. Welch: (r) Change of colour in a specimen of Mellivora ratel living in the society's gardens; (2) a comparative examination of three living specimens of $F$ elis tigris sondaica, with notes on an old Javan male.-Dr. W. E. Agar: The nesting habits of the tree-frog; Phyllomedusa sauvagii. This frog makes a nest suspended from bushes overhanging a pool, into which the tadpoles drop when they are hatched. The nest is constructed from a number of leaves, the lower ends of which are drawn 